\title{
Rencana Lansekap Wisata Edutani Di Kebun Percobaan Fakultas Pertanian, Universitas Udayana
}

\author{
COKORDA GEDE ALIT SEMARAJAYA*, KOMANG ARTHAWA LILA, \\ ANAK AGUNG GEDE DALEM SUDARSANA, LURY SEVITA YUSIANA
}

\author{
1Program Studi Arsitektur Pertamanan, Fakultas Pertanaian, Universitas Udayana, \\ JI. PB Sudirman Denpasar, Indonesia
}

*Email: coksemarajaya@unud.ac.id

\begin{abstract}
Bali is an agrarian island but the interests of Balinese people are very limited to the agricultural sector. Faculty of Agriculture-Udayana University is primarily responsible for improving human resources in agriculture and the development of the agricultural sector in Bali. One of the facilities owned by the faculty is experimental garden. In addition to being a center of education and research, the experimental garden is also expected to introduce the agricultural field through recreational activity to thel public. By developing experimental garden as a tourist destination requires a study to determine a tourist attraction. However, having a tourist attraction will not ensure if it is matched with the experimental garden management as well as the tourism development program. This study aims to plan agricultural landscape educational tourism (Edutani) in faculty experimental garden of Udayana University. The research method was conducted with Gold (1980) planning of recreation activity approach which is consist with some steps i.e. inventory, analysis, synthesis, concept and landscape plan. This research resulted a landscape plan for Faculty of Agriculture experiment garden for edutani tourism development.
\end{abstract}

Keywords: edutani tour, experimental garden, landscape plan, tourism attractions

\section{Pendahuluan}

Bali merupakan pulau agraris dengan berbagai komoditi pertanian, seperti halnya padi, salak, jeruk, durian, manggis, pisang, dan sebagainya. Komoditi pertanian tidak hanya memenuhi kebutuhan pangan bagi masyarakat Bali, melainkan juga dipergunakan sebagai sarana persembahyangan umat Hindu di Bali. Tingginya kebutuhan produk pertanian tidak diimbangi dengan minat generasi muda bekerja di sektor pertanian. Pemuda perdesaan merepresentasikan pekerjaan pertanian secara ekonomi masih menguntungkan, tetapi kurang mampu memberi status sosial terhormat di dalam maupun di luar komunitasnya. Pada akhirnya pekerjaan pertanian lebih memberi kenyamanan jika diposisikan sebagai pekerjaan pendukung (Tarigan, 2004).

Sesuai tujuan pendidikan tinggi, yaitu menghasilkan lulusan yang menguasai cabang ilmu pengetahuan dan/atau teknologi untuk memenuhi kepentingan nasional dan peningkatan daya saing bangsa (Undang-undang Republik Indonesia, 2012), maka Fakultas Pertanian Universitas Udayana (FP Unud) berupaya memberikan pendidikan dan pemahaman tentang pentingnya sektor pertanian. Kebun Percobaan FP Unud merupakan wadah yang dipersiapkan sebagai sarana belajar bagi civitas akademika FP Unud tentang berbagai hal terkait pertanian, mulai dari pengelolaan lahan, penanaman, pemeliharaan, 
panen, pasca panen, bahkan pemasaran produk pertanian. Dengan demikian, diharapkan Kebun Percobaan FP Unud dapat menjadi salah satu destinasi wisata Kota Denpasar yang dapat mendekatkan masyarakat kepada Kebun Percobaan FP Unud sehingga membuka pemahaman dan minat masyarakat untuk kembali menekuni sektor pertanian. Penelitian ini bertujuan untuk merencanakan lansekap wisata edukasi pertanian (edutani) di Kebun Percobaan FP Unud.

\section{Metode Penelitian}

Penelitian dilakukan pada Kebun Percobaan FP Unud. Penelitian dilakukan selama lima bulan yang dimulai pada Maret 2016 hingga Agustus 2016. Penelitian dilakukan pada areal Kebun Percobaan FP Unud dengan batasan penelitian pada rencana lansekap wisata edutani yang menitikberatkan pada aktivitas wisata berbasis edukasi dan rekreasi. Penelitian ini berupa kajian secara deskriptif kualitatif dengan mengemukakan permasalahan dan menyelesaikan masalah berdasarkan tahapan penelitian. Tahapan penelitian didasarkan pada tahapan menghasilkan karya arsitektur lanskap yang dikemukakan oleh Gold (1980) yaitu inventarisasi, analisis, sintesis, konsep, dan rencana lansekap. Secara rinci tahapan ini akan dijelaskan sebagai berikut. (Gambar 1).

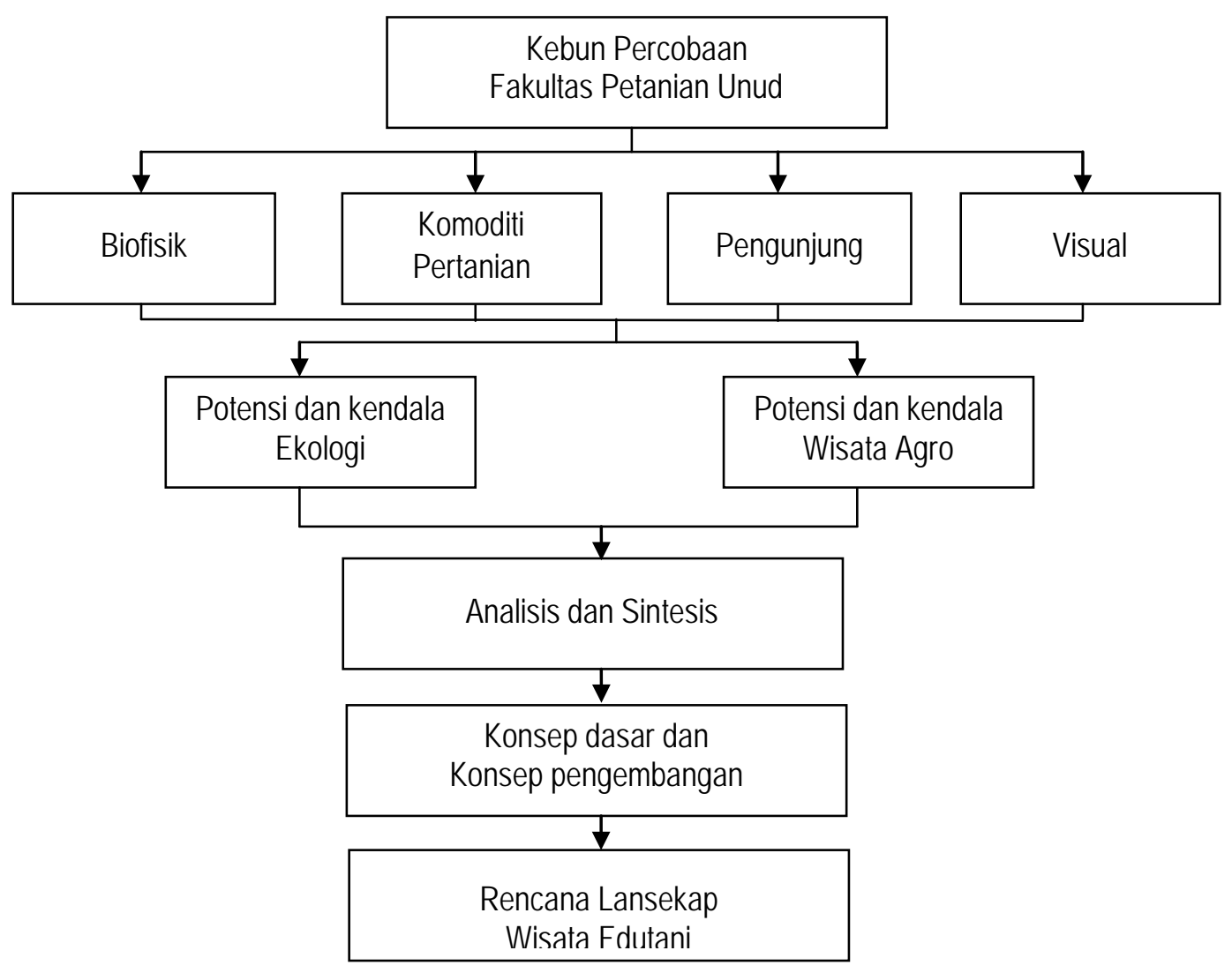

Gambar 1. Tahapan Penelitian 


\section{Hasil dan Pembahasan}

\subsection{Potensi Ekologi}

Elemen-elemen pembentuk tapak alami meliputi tanah, topografi, iklim, hidrologi, vegetasi, satwa, dan manusia. Elemen pembentuk tapak alami merupakan elemen dasar yang membentuk lansekap dan menjadi sumber daya bagi lansekap tersebut. Pengembangan lansekap menjadi sangat baik apabila didasarkan pada sumber daya lahan yang dimiliki (Gunn, 1994).

Kebun Percobaan FP Unud berada di Kota Denpasar yang termasuk dataran rendah dengan ketinggian berkisar antara 0-25 mdpl (BPS Kota Denpasar, 2016). Hal ini berpengaruh pada komoditi tanaman pertanian yang ditanam, yaitu tanaman dataran rendah tropis. Topografi relatif datar yaitu berkisar antara $0-8 \%$ dengan jenis tanah latosol coklat kekuningan (Bappeda, 2016). Kondisi ini menjadikan Kebun Percobaan sesuai sebagai kebun pertanian karena mampu menampung banyak aktivitas pertanian di dalamnya. Iklim terdiri atas suhu, curah hujan dan intensitas matahari. Ketiga elemen iklim ini berpengaruh terhadap pertumbuhan tanaman. Berdasarkan data BPS Kota Denpasar (2016), suhu rata-rata Kota Denpasar adalah $22^{\circ} \mathrm{C}-34^{\circ} \mathrm{C}$, curah hujan sepanjang tahun 2016 adalah $1447 \mathrm{~mm}$ dengan jumlah hari hujan sebanyak 111 hari, sedangkan intensitas penyinaran matahari adalah 57\%. Data iklim menunjukkan Kebun Percobaan FP Unud cocok bagi pengembangan pertanian. Potensi sumber air yang digunakan pada Kebun Percobaan FP Unud berasal dari air tanah dengan 2 buah sumur yang terletak di bagian timur dan selatan tapak. Vegetasi yang terdapat pada Kebun Percobaan FP Unud terdiri atas tanaman pangan dan tanaman hortikultura. Tanaman yang ada di Kebun Percobaan FP Unud merupakan komoditi yang sedang dikembangkan dan diteliti oleh sivitas akademika FP Unud. Saat ini Kebun Percobaan sedang mengembangkan dan melakukan penelitian pada beberapa komoditi, seperti pisang, terong, gondo, cabai, stroberi, bunga gemitir, buah naga dan labu botol. Kebun Percobaan FP Unud tidak secara spesifik memelihara satwa. Satwa yang ada hanya berupa satwa akibat terciptanya suatu kondisi ekosistem tertentu. Satwa yang ada di tapak seperti pada ekosistem kebun pada umum lainnya. Pengguna Kebun Percobaan FP Unud saat ini adalah civitas akademika FP Unud, yaitu dosen, pegawai, dan mahasiswa. Dosen dan mahasiswa menggunakan Kebun Percobaan sebagai lokasi pendidikan dan penelitian. Sedangkan pegawai bertindak sebagai pemelihara Kebun Percobaan.

\subsection{Potensi Wisata}

Komoditi pertanian yang ada di Kebun Percobaan FP Unud adalah Buah Naga (Hylocereus undatus), Bunga Gemitir/marigold (Tagetes erecta), Terong (Solanum melongena), Stroberi/strawberry (Fragaria virginiana), Pisang (Musa paradisiaca), Cabai (Capsicum frutescens L.), Labu botol/butternut (Cucurbita moschata), Jagung (Zea mays), Gondo, Bayam (Spinacia oleracea) dan sayuran hidroponik. Perbedaan komoditi tersebut memberi potensi bagi pengembangan wisata, karena menampilkan berbagai komoditas unggulan yang bisa dinikmati pengujung.

Atraksi panen merupakan atraksi yang sangat diminati pengunjung pada obyek wisata pertanian. Akan tetapi aktivitas pertanian sangat bergantung pada musim, sehingga panen hanya dapat dilakukan pada periode waktu tertentu. Kesulitan dialami ketika pengunjung datang pada saat tidak panen, karena atraksi panen tidak dapat ditunjukkan. Solusinya adalah beberapa komoditi merupakan komoditi yang cepat panen dan di tanam berbeda waktu sehingga dapat memberikan atraksi panen berbeda bagi tiap pengunjung yang datang. Selain itu, kekuatan penyajian atraksi tidak selalu bergantung pada aktivitas panen 
saja, melainkan dapat menampilkan atraksi lain terkait proses pertanian. Atraksi buatan (artifisial) sengaja diciptakan untuk menarik minat wisatawan untuk berkunjung (Arjana, 2015).

Kondisi visual Kebun Percobaan FP Unud bersumber dari dalam tapak. Pagar pembatas yang tinggi mengelilingi tapak, menyulitkan pengunjung di dalam tapak untuk melihat pemandangan di luar tapak. Penataan tapak menjadi kunci dalam menghadirkan visual yang baik. Pemanfaatan tanaman dan penanamannya yang terencana dapat memberikan daya tarik visual bagi tapak. Contohnya penggunaan tanaman Buah Naga sebagai tanaman pembatas dengan menempelkannya pada tiang beton. Menampilkan keindahan bentuk tanaman yang terjajar rapi dengan hiasan buah (Gambar 2a). Tanaman pisang yang merupakan tanaman penelitian ditanam dengan rapi menjai daya tarik karena warna daun dan buahnya (Gambar 2b). Selain itu, tanaman dengan daun berwarna dan tanaman bunga juga menjadi daya tarik wisata.

Kebun Percobaan FP Unud merupakan tapak dengan tujuan pengembangan bagi pendidikan dan penelitian pertanian. Dalam memperkenalkan pendidikan pertanian, maka Kebun ini menjadi etalase yang sangat baik untuk menunjukkan aktivitas pertanian khususnya pertanian perkotaan dengan lahan terbatas. Produk-produk unggulan dapat dihasilkan di sini sehingga menarik minat pengunjung dari luar Unud.

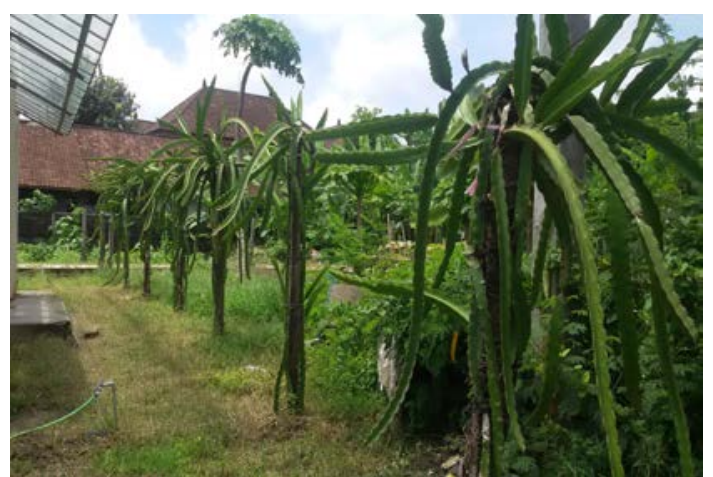

(a)

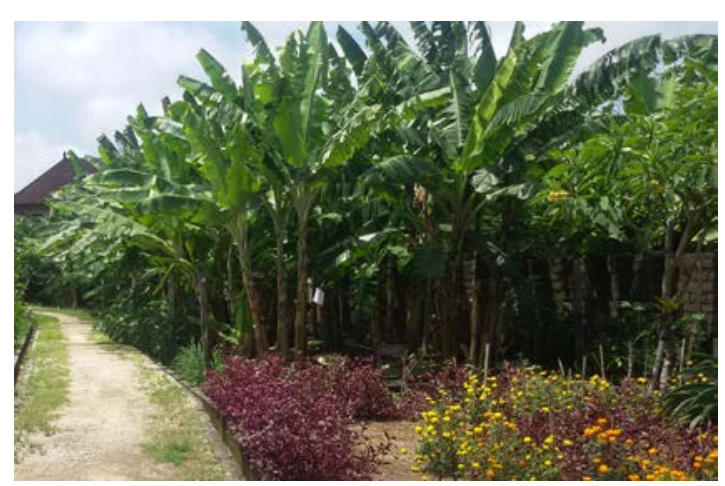

(b)

Gambar 2. Visual Tapak Kebun Percobaan FP Unud

\subsection{Program Pengembangan}

Kebun Percobaan FP Unud diarahkan untuk memenuhi fungsinya sebagai lokasi pendidikan dan penelitian yang menjadi etalase dalam memamerkan pertanian lahan kering di perkotaan. Berbagai komoditi yang diaplikasikan di sini menjadi contoh dapat diaplikasinkan di lokasi lain dengan berbagai tujuan dan manfaatnya. Pengembangan Kebun Percobaan FP Unud diharapkan mampu membangkitkan peranian di Bali. Berdasarkan potensi ekologi dan potensi wisata dihasilkan program pengembangan Kebun Percobaan FP Unud.

Program pengembangan Kebun Percobaan FP Unud berdasarkan analisis adalah

1. Pengembangan Komoditi.

Komoditi yang ditanaman merupakan tanaman pertanian yang bernilai ekonomi tinggi dan memberi manfaat lebih bagi petani. Komoditi tersebut didasarkan pada ekologi tanaman yang mampu hidup dengan kondisi tanah dan iklim dataran rendah. Melalui pengembangan komoditi ini pengunjung diajak untuk mengenal komoditi yang mampu memberikan manfaat ekonomi. Di samping itu, komoditi yang langka juga dikembangkan untuk melestarikan berbagai spesies tanaman pertanian yang memberi berbagaik manfaat lebih bagi manusia. 
2. Pengembangan Benih dan Bibit Unggul

Kebun Percobaan FP Unud tidak hanya mengembangkan komoditi tanaman yang memiliki nilai ekonomi tetapi juga menghasilkan benih dan bibit unggul. Hal ini merupakan pengembangan dari fungsi Kebun Percobaan FP Unud sebagai lokasi penelitian. Hasil-hasil penelitian memiliki ruang untuk dapat dipromosikan pada pengujung.

3. Pemanfaatan Lahan Optimal

Lahan Kebun Percobaan FP Unud yang kecil memerlukan penataan agar dapat dimanfaatkan dengan optimal. Pemanfaatan lahan ditujukan untuk memenuhi berbagai aktivitas yang akan direncanakan, baik berupa aktivitas pendidikan, penelitian, maupun rekreasi. Penataan lahan berdasarkan pemanfaatannya mendasari pembuatan zonasi. Penataan bagi penanaman komoditi didasarkan pada estetika.

Pemenuhan fungsi rekreasi pada Kebun Percobaan FP Unud diarahkan pada penataan ruang dan aktivitas yang memberikan kesenangan dan kenyamanan bagi pengunjung. Lokasi kebun yang relatif datar memungkinkan untuk pengembangan berbagai kegiatan rekreasi. Hal ini sejalan dengan kesesuaian lahan untuk taman rekreasi berdasarkan USDA tahun 1968 yaitu 0 - 8 \% (Hardjowigeno dan Widiatmaka, 2007). Kegiatan rekreasi diarahkan untuk mendukung kegiatan edukasi. Edukasi akan lebih mudah dipahami dan memorable apabiladiterima dengan cara yang menyenangkan. Kegiatan rekreasi dikembangkan melalui program-program berikut.

1. Program Pengenalan Komoditi

Program ini bertujuan untuk mengenalkan berbagai komoditi yang ada di Kebun Percobaan FP Unud kepada pengunjung. Pengenalan komoditi merupakan kegiatan mengajak pengunjung mengenal lebih dekat berbagai jenis tanaman pertanian yang memiliki nilai ekonomi maupun yang langka mulai dari benih, morfologi tanaman, hingga bunga dan buah. Pengenalan komoditi memberikan kesempatan bagi pengunjung untuk jalan-jalan dan menikmati keindahan pemandangan di dalam Kebun Percobaan FP Unud.

2. Program Penanaman

Program ini bertujuan untuk mengedukasi pengunjung tentang berbagai teknik penanaman. Program penanaman dimulai dari pemilihan benih dan/atau bibit yang baik untuk ditanaman, berbagai teknik penanaman dan teknik perbanyakan. Program penanaman memberikan peluang pengunjung untuk mencoba menanam dan memperbanyak tanaman agar dapat melakukan sendiri. Program penanaman juga menceritakan tentang berbagai manfaat yang diperoleh dari tanaman yang ditanam.

3. Program Pemeliharaan Tanaman

Program pemeliharaan tanaman bertujuan untuk mengenalkan pengunjung tentang pentingnya memelihara tanaman melalui berbagai teknik pemeliharaan tanaman yang bergantung pada komoditas yang di tanam. Program ini memberikan kesempatan bagi pengunjung untuk ikut berpartisipasi dalam memelihara tanaman mulai dari menyiram, memupuk, melakukan penjarangan, pemangkasan, dan mengatasi hama dan penyakit tanaman. Kegiatan ini disesuaikan dengan kondisi tanaman pada saat kunjungan.

4. Program Pemanenan

Program pemanenan bertujuan untuk mengajak pengunjung menikmati hasil panen. Program ini dilakukan hanya pada saat panen berlangsung. Program ini dibuat melalui perencanaan yang matang agar panen dapat dilakukan berkala. Program ini mengajak pengunjung untuk dapat selektif memilih yang sap dipanen agar nantinya laku dijual. 
5. Program Pasca Panen

Program pasca panen bertujuan untuk memberikan pengetahuan teknik pengolahan hasil panen selanjutnya sebelum di jual atau di simpan. Program ini dikhususkan bagi hasil panen yang mudah rusak atau busuk. Pengunjung dikenalkan pada teknologi pasca panen dan teknik pengemasan yang dapat memberi nilai ekonomi lebih bagi produk panen tersebut.

6. Program Pengembangan Kuliner Sehat

Program pengembangan kuliner sehat merupakan program lanjutan dari pasca panen. Program ini bertujuan untuk mengolah hasil pertanian menjadi kuliner yang sehat. Pengunjung diajak memilih bahan yang sehat dan diajarkan memasak yang sehat dengan hasil masakan yang lezat. Bahan utama kuliner tersebut menggunakan hasil panen yang ada di Kebun Percobaan FP Unud.

7. Program Pasar Modern

Program pasar modern ditujukan untuk melihat seluruh hasil panen dan hasil olahan panen yang ada di Kebun Percobaan FP unud. Program ini juga memperbolehkan pengunjung untuk membeli hasil panen dan hasil olahan panen dengan kualitas tinggi dan harga bersaing.

\subsection{Konsep}

Kebun Percobaan FP Unud sebagai kawasan wisata edutani ditata dengan konsep dasar edukasi yang dikemas dalam kegiatan rekreasi. Edukasi lebih mudah dipahami ketika diterima dengan cara yang menyenangkan. Edukasi pertanian yang diberikan meliputi tanaman yang sehat, produk tanaman sehat, hingga makanan sehat. Hal ini sejalan dengan yang dikemukakan oleh Arjana (2016) bahwa wisata edutani merupakan perjalanan yang dilakukan oleh seseorang atau sekelompok orang pada obyek wisata yang memanfaatkan usaha agro dengan tujuan memperluas pengetahuan, pengalaman rekrerasi dan hubungan di bidang pertanian.

Konsep dasar di atas menjadi dasar bagi penataan ruang, sirkulasi dan tata hijau dalam pengembangan wisata edutani di Kebun Percobaan FP Unud. Penataan ruang dikembangkan berdasarkan konsep dasar dengan memadukan kegiatan edukasi dan rekreasi. Kegiatan tersebut memerlukan pemanfaatan berbagai lokasi untuk memenuhi kebutuhan akan ruang edukasi dan rekreasi. Penataan ruang di bagi menjadi empat zona, yaitu

1. Zona Komoditi

Merupakan zona yang menghadirkan kegiatan inti melalui berbagai komoditi pertanian. Atraksi wisata didasarkan pada program pengenalan komoditi, penanaman, pemeliharaan tanaman dan panen.

2. Zona Produk

Merupakan zona yang menghadirkan kegiatan inti melalui berbagai pengelolaan produk pertanian. Atraksi wisata pada zona ini didasarkan pada program pasca panen dan pengembangan kuliner sehat.

3. Zona Pameran

Merupakan zona yang menghadirkan kegiatan penunjang melalui berbagai kegiatan penunjang pertanian. Atraksi wisata didasarkan pada program pasar modern yang menyediakan berbagai produk pertanian berupa benih, bibit, pupuk, pestisida, hasil panen, maupun produk olahan makanan hingga buku-buku pertanian yang 
dihasilkan oleh sivitas akademika FP Unud serta berbagai rekanan dan petani binaan.

4. Zona Pelayanan

Merupakan zona yang menghadirkan kegiatan penunjang berupa pusat informasi, lokasi berkumpul, parkir, gudang alat pertanian, toilet, dan sebagainya yang mendukung terlaksananya kegiatan wisata edutani.

Sirkulasi didasarkan atas konsep dasar dan mendukung penataan ruang. Konsep sirkulasi diarahkan untuk memudahkan pengunjung untuk menjangkau titik aktivitas dan memudahkan pengunjung beraktivitas di dalamnya. Sirkulasi yang dibuat dikhususkan bagi pejalan kaki. Bagi kendaraan yang dibawa disediakan tempat parkir. Sirkulasi pejalan kaki dibagi menjadi 3 jenis, yaitu

1. Jalan Primer

Jalan primer merupakan jalan utama yang menghubungkan beberapa blok lokasi penanaman. Masing-masing blok diisi oleh kelompok tanaman yang berbeda.

2. Jalan Sekunder

Jalan sekunder merupakan jalan yang menghubungkan antar petak-petak lahan dalam satu blok. Masing-masing petakan lahan diisi tanaman yang sama. Jalan sekunder memudahkan pengunjung untuk masuk ke dalam petakan lahan, sehingga pengujung lebih dekat dengan tanaman.

3. Jalan Tersier

Jalan tersier merupakan jalan yang berada di dalam petakan lahan. Jalan ini membawa pengunjung untuk terjun langsung saat menanam, memelihara tanaman, maupun panen.

Penataan vegetasi didasarkan pada fungsi masing-masing ruang pada kegiatan wisata edutani. Konsep tata hijau adalah penataan vegetasi yang mampu memberi kenyamanan bagi pengunjung dengan menghadirkan suasana hijau di tengah kota Denpasar. Pengunjung yang berada di tapak mendapatkan suasana berbeda yang jauh dari nuansa kota. Penataan vegetasi diarahkan untuk dapat menghadirkan iklim mikro yang nyaman bagi pengunjung dengan memberikan tanaman peneduh tetapi sinar matahari dapat diperoleh tanaman komoditi pertanian dengan baik. Penataan diarahkan terbuka agar sirkulasi angin dapat masuk dan keluar dengan baik. Untuk menunjang konsep tersebut dibutuhkan vegetasi dengan fungsi sebagai berikut.

1. Vegetasi yang berfungsi sebagai komoditi pertanian.

2. Vegetasi yang berfungsi sebagai tanaman estetik

3. Vegetasi yang berfungsi sebagai tanaman peneduh.

4. Vegetasi yang berfungsi sebagai tanaman pembatas.

Penaataan fungsi vegetasi dalam masing-masing zona dapat dilihat pada tabel 1.

Tabel 1 Fungsi Vegetasi pada Zona Penataan Ruang

\begin{tabular}{lll}
\hline No & Zona & Fungsi Vegetaasi \\
\hline $1 \quad$ Komoditi & - Komoditi pertanain, berupa komoditi yang ditanam untuk \\
& pendidikan, penelitian dan koleksi tanaman. \\
& - Tanaman pembatas, dapat berupa tanaman yang menjadi \\
& pembatas antar blok petakan, blok komoditi, atau menjadi \\
& pembatas dengan elemen keras seperti gedung dan pagar. \\
& Sebagai pembatas pada pagar, maka tanaman yang \\
& digunakan berupa tanaman merambat.
\end{tabular}




\begin{tabular}{lll}
\hline No Zona & \multicolumn{1}{c}{ Fungsi Vegetaasi } \\
\hline 2 Produk & - Tanaman estetik, berupa tanaman yang memberikan \\
& nuansa keindahan visual agar pengunjung merasa nyaman. \\
& - Tanaman peneduh, berupa tanaman yang dapat \\
& menghadirkan iklim mikro yang nyaman bagi pengguna. \\
& - Tanaman peneduh, berupa tanaman yang memberikan \\
& kenyamanan sehingga pengunjung senang berada di zona ini. \\
- & Tanaman estetik, berupa tanaman secara visual menarik \\
& dan membangkitkan keinginan pengunjung untuk dapat ke \\
& zona ini. \\
- & Komoditi pertanian, sebagai etalase agar pengunjung dapat \\
& melihat vegetasi yang menjadi komoditi pada Kebun \\
& Percobaan FP unud \\
- & Tanaman peneduh, sebagai tanaman yang menghadirkan \\
& suasana nyaman sehingga pengunjung merasa diterima \\
& dengan baik di kawasan wisata edutani ini. \\
& - Tanaman estetik, sebagai daya tarik bagi pengunjung \\
& secara visual agar pengunjung tertarik untuk melihat \\
& keindahan lebih lanjut yang ditawarkan pada Kebun \\
& Percobaan FP Unud. \\
\hline
\end{tabular}

\subsection{Rencana Lansekap Wisata Edutani}

Rencana lansekap wisata edutani di Kebun Percobaan FP Unud dibuat berdasarkan konsep pengembangan pada penataan ruang, sirkulasi, dan vegetasi. Setiap ruang memiliki atraksi yang berbeda, dan setiap atraksi menghadirkan kegiatan wisata yang berbeda. Atraksi didasarkan pada program pengembangan kegiatan wisata. fasilitas disediakan untuk menunjang kegiatan yang direncanakan. Keterkaitan antara ruang, atraksi, aktivitas dan fasilitas disajikan pada Tabel 2.

Tabel 2 Keterkaitan antara ruang, aktivitas, dan fasilitas

\begin{tabular}{|c|c|c|c|}
\hline No & Ruang & Aktivitas & Fasilitas \\
\hline 1 & $\begin{array}{l}\text { Zona } \\
\text { Komoditi }\end{array}$ & $\begin{array}{l}\text { - Pengenalan Komoditi: mengenal } \\
\text { benih/bibit, mengenal morfologi } \\
\text { tanaman, mengenal produk } \\
\text { tanaman, menikmati } \\
\text { pemandangan } \\
\text { - Penanaman : memilih benih/bibit } \\
\text { yang baik untuk ditanam, } \\
\text { mencampur media dengan pupuk, } \\
\text { membuat lubang tanam, } \\
\text { menanam, dan menyiram } \\
\text { tanaman, teknik budidaya } \\
\text { tanamandengan biji, stek, } \\
\text { cangkok, dan sebagainya. } \\
\text { - Pemeliharaan tanaman : } \\
\text { penyiraman, pemupukan, } \\
\text { penyiangan, pendagiran, } \\
\text { peniarangan, dan sebagainya. }\end{array}$ & $\begin{array}{l}\text { - Petak dan blok komoditi } \\
\text { pertanian } \\
\text { - Lokasi pembibitan } \\
\text { - Jalur primer, sekunder, tersier } \\
\text { - Peralatan untuk budidaya, } \\
\text { penanaman, pemeliharaan, } \\
\text { dan pemanenan } \\
\text { - Gazebo dan tanaman } \\
\text { peneduh untuk beristirahat } \\
\text { - Sumber air }\end{array}$ \\
\hline
\end{tabular}




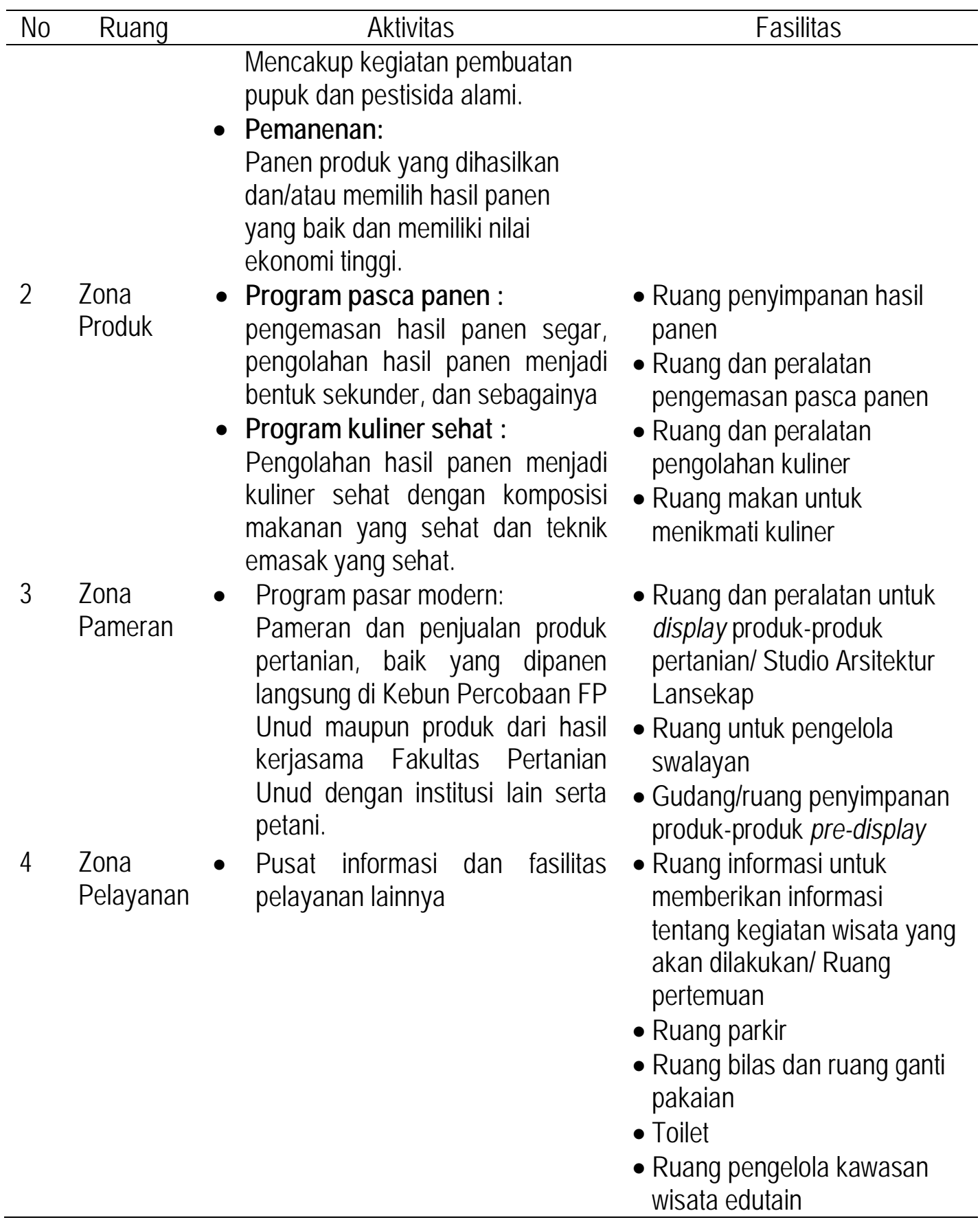

Konsep perencanaan lansekap wisata dibagi menjadi tiga skala yaitu perencanaan tapak (site plan), perencanaan daerah tujuan wisata (destination plan), dan perencanaan regional (regional plan) (Gunn, 1993). Berdasarkan hal tersebut, maka penelitian ini dikembangkan dalam skala perencanaan tapak (siteplan). Siteplan merupakan produk akhir peneitian ini (Gambar 3).

\section{Simpulan}

Potensi wisata edutani Kebun Percobaan Fakultas Pertanian memiliki potensi ekologi dan potensi wisata. potensi ekologi berupa tanah subur, topografi datar, iklim nyaman, sumber air tersedia, vegetasi berupa tanaman pangan dan tanaman hortikultura untuk pendidikan dan penelitian, satwa alami, dan pengguna yang intens dari sivitas akademika 
Fakultas Pertanian Unud. Potensi wisata yang ada pada tapak berupa komoditi pertanian yang memiliki nilai jual dan ditata ditapak yang memberikan keindahan visual.

Rencana lansekap wisata edutani di Kebun Percobaan Fakultas Pertanian ditata berdasarkan konsep edukasi yang dikemas dalam kegiatan rekreasi. Konsep ini dikembangkan bagi penataan ruang, sirkulasi, dan vegetasi. Penataan ruang dibagi menjadi empat zona, yaitu komoditi, produk, pameran, dan pelayanan. Penataan sirkulasi dibagi menjadi sirkulasi primer, sirkulasi sekunder, dan sirkulasi tersier. Penataan vegetasi berdasarkan fungsi yaitu sebagai komoditi pertanian, tanaman estetik, tanaman peneduh, dan tanaman pembatas.

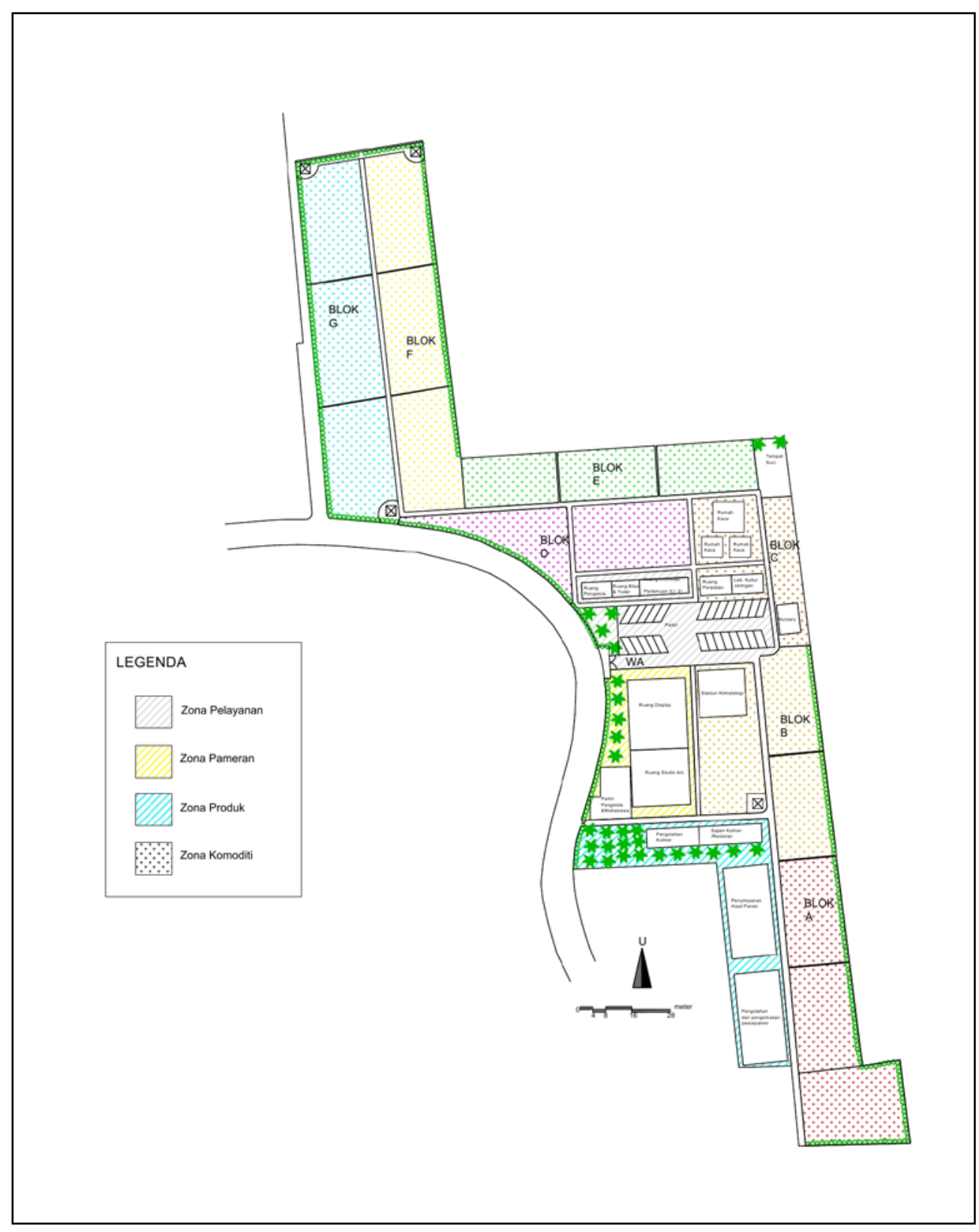

Gambar 3. Siteplan Wisata Edukasi Kebun Percobaan Fakultas Pertanian Unud 


\section{Daftar Pustaka}

Arjana IGB. 2015. Geografi Pariwisata dan Ekonomi Kreatif. Jakarta: PT. Raja Grafindo Persada.

Badan Pusat Statistik (BPS) Kota Denpasar. 2016. Sosial dan Kependudukan: Iklim. https://denpasarkota.bps.go.id/Subjek/view/id/151\#subjekViewTab3|accordion-daftarsubjek1 [diunduh 13 Oktober 2016, pkl 13.00]

Gold SM. 1980. Recreation Planning and Design. New York: McGraw - Hill Book Company.

Gunn CA. 1994. Tourism Planning Basics, Concepts, Cases. Third Edition. London: Tylor \& Francis.

Hardjowigeno S, Widiatmaka. 2007. Evaluasi Kesesuaian Lahan dan Perencanaan Tata Guna Lahan. Yogyakarta: Gadjah Mada University Press.

Pemerintah Kota Denpasar. 2016. Rencana Kerja Pembangunan Daerah Kota Denpasar. https://www.bappenas.go.id/files/rpjmd_dan_rkpd_kab_kota/RKPD\%20Kota\%20Denp asar\%202016.pdf [diunduh 30 Oktober $201 \overline{7}$ pkl. 12.00].

Pemerintah Republik Indonesia. 2012. Undang-undang Republik Indonesia Nomor 12 Tahun 2012 Tentang Pendidikan Tinggi. Jakarta.

Tarigan H. 2004. Representasi Pemuda Pedesaan mengenai Pekerjaan Pertanian: Kasus pada Komunitas Perkebunan Teh Rakyat di Jawa Barat. ICASERD Working Paper No. 29. Pusat Penelitian dan Pengembangan Sosial Ekonomi Pertanian. Badan Penelitian dan Pengembangan Pertanian. Departemen Pertanian. http://pse.litbang.pertanian.go.id/ind/pdffiles/WP_29_2004.pdf [diunduh 30 Oktober 2017 pkl 13.00] 